\title{
Internal Validation of Rapid and Performant Method for Carotenoids Determination in Tomato Waste Powder by HPLC
}

\author{
LUMINIȚA CATANĂ ${ }^{1}$, MONICA CATANĂ ${ }^{1 *}$, ENUȚA IORGA ${ }^{1}$, ADRIAN CONSTANTIN ASĂNICĂ $\breve{2}^{2}$, \\ MONICA-ALEXANDRA LAZĂR ${ }^{1}$, ANDA-GRAȚIELA LAZĂR ${ }^{1}$, NASTASIA BELC ${ }^{1}$, GINA PÎRVU ${ }^{1}$ \\ ${ }^{1}$ National R\&D Institute for Food Bioresources - IBA Bucharest, 6 Dinu Vintila Str., 021102, Bucharest, Romania \\ ${ }^{2}$ University of Agronomic Sciences and Veterinary Medicine of Bucharest, Faculty of Horticulture, 59 Marasti Blvd, \\ 011464, Bucharest, Romania
}

\begin{abstract}
An analytical method was developed and validated for separation, detection and quantification of carotenoids (all-trans lutein, $\beta$-carotene and all-trans lycopene) in tomato waste powder by highperformance liquid chromatography (HPLC-DAD). Extraction of carotenoids was achieved in acetone under nitrogen atmosphere and magnetic stirring. Carotenoids were separated on a reverse-phase C30, $3 \mu \mathrm{m}$ column $(250 \times 4.6 \mathrm{~mm})$ coupled to a $20 \times 4.6 \mathrm{~mm}$ C30 guard column using mobile phases consisting of (A) methanol/ water (98:2, v/v), (B) methanol/water $(95: 5, v / v)$ and $(C)$ methyl tert-butyl ether. The method has a good sensitivity $(L O D=0.161-0.333 \mu \mathrm{g} / \mathrm{mL}$ and $L O Q=0.484-1.000 \mu \mathrm{g} / \mathrm{mL})$ and a good precision ( $R D S(r)=0.67-1.15 \%$ for injection repeatability; $R S D(r)=1.02-2.14 \%$ for analysis repeatability intra-day; $R S D(r)=1.23-$ $2.43 \%$ for intermediate precision; $R S D(R)=1.57-3.07 \%$ for intra-laboratory reproducibility. The method was applied byanalyzing 8 tomato waste powders, obtained through tomatoes processing as juice. Their carotenoids content varied in the following ranges: $1.474-2.452$ $\mathrm{mg} / 100 \mathrm{~g}$ for all-trans lutein; 9.645 - $11.587 \mathrm{mg} / 100 \mathrm{~g}$ for $\beta$-carotene; 60.150 - $64.855 \mathrm{mg} / 100 \mathrm{~g}$ for all-trans lycopene.
\end{abstract}

Keywords: carotenoids, validation, HPLC-DAD, powder, tomato waste

Tomatoes (Lycopersicon esculentum L.) are cultivated worldwide for their fruits, registering an annual production over 170 million tones in 2014 [1]. Regular consumption of tomatoes and tomato processed products was corelated with a significant decrease of susceptibility to different types of cancer and cardiovascular diseases [2]. These positive effects are due to the antioxidant compounds present in tomatoes, such as vitamins $\mathrm{C}$ and $\mathrm{E}$, carotenoids, polyphenols, which have a key-role in mechanisms for health protection, through free-radicals neutralization [3]. Also, tomatoes are an important source of oligoelements, such as selenium, copper, manganese and zinc, which are co-factors of antioxidant enzymes [4]. Due to the complex biochemical composition, consumption of fresh and processed tomatoes (juice, purée, paste, ketchup, etc.) has benefficial effects on human body: cardioprotective [5], antiplaquette (inhibit plaquettes agregation) [6], decrease of triglycerides and cholesterol levels in blood [7], reduction of oxidative stress induced by postprandial lipemia (increase of lipids level in blood after lunch) [8]. Research performed by Riccioni $e t$ al. [9] showed that, in case of individuals with atherosclerose, there were registered serum low concentrations of lycopene. Tomatoes and tomato processed products are an important source of lycopene, which was demonstrated to have antioxidant properties and a potential role to prevent cronic diseases [2]. Besides lycopene, tomatoes contain $\alpha$-, $\beta-, \gamma-, \delta$-carotene and lutein and also neurosporene, phytoene, and phytofluene [10], which are believed to act synergistically with lycopene [11].

Millions of tomato tones are annually processed to produce tomato juice, sauces, purées, paste and canned tomatoes, resulting large quantities of tomato skin, pulp and seeds, which constitute industrial waste [12]. Thus, World Processing Tomato Council estimated that aproximately 40 million tones of tomatoes were processed at world level in 2014, to obtain tomato juice, paste, purées, ketchup, canned tomatoes and other food products [13]. When tomatoes are processed to obtain ketchup, sauces or juice, results waste which represents 3-7\% of weight of tomatoes introduced in the manufacture process [14].

Studies performed showed that in epicarp are found the highest concentrations of fenolic compounds, flavonoides and lycopene and ascorbic acid. Also tomato epicarp has the highest antioxidant activity in comparison to the pulp and seed fractions $[15,16]$. Also, much studies showed that tomato seeds are rich in nutrients: carotenoids, proteins, polyphenols, mineral elements, fibres and oils [16-21].

*email: email: mcatana1965@gmail.com 
Studies performed by Rubashvili et al. (2018) showed that in case of tomato skin $\beta$-carotene content varied in the range $8.39-12.75 \mu \mathrm{g} / \mathrm{g}$, and lycopene content in the range $165.11-179.56 \mu \mathrm{g} / \mathrm{g}$ [22]. According to the recent studies performed by Nour et al. (2018) dried tomato wastes, consisting of about $22.2 \%$ seeds and $77.8 \%$ pulp residues and skins, have complex biochemical composition represented by: $946.5 \mathrm{~g} / \mathrm{kg}$ dry matter, $176.2 \mathrm{~g} / \mathrm{kg}$ crude protein, 21.9 $\mathrm{g} / \mathrm{kg}$ crude fat, $524.4 \mathrm{~g} / \mathrm{kg}$ crude fiber, $42.1 \mathrm{~g} / \mathrm{kg}$ ash, $172.4 \mathrm{~g} / \mathrm{kg}$ total amino acids, unsaturated fatty acids (represent $77.04 \%$ of the total fatty acids), saturated fatty acids (represent $22.72 \%$ of the total fatty acids), $1229.5 \mathrm{mg}$ GAE$/ \mathrm{kg}$ total phenolics, $415.3 \mathrm{mg} \mathrm{QE} / \mathrm{kg}$ total flavonoids, $510.6 \mathrm{mg} / \mathrm{kg}$ lycopene, $95.6 \mathrm{mg} / \mathrm{kg} \beta$-carotene [23].

Strati et al. (2012) developed a method for carotenoids determination in tomato wastes by high-performance liquid chromatography (HPLC-DAD), using a YMC (Tokyo, Japan) C30 column $(250 \times 4.6 \mathrm{~mm}$ I.D., $5 \mu \mathrm{m}$ particle). A mobile phase of acetonitrile (A), 1-butanol (B) and methylene chloride (C) with the following gradient elution was used: $69.3 \%$ A, $29.7 \%$ B and $1.0 \%$ C, initially; increased to $67.2 \%$ A, $28.8 \% \mathrm{~B}$ and $4 \%$ C, in the first $10 \mathrm{~min} ; 61.6 \%$ A, 26.4\% B and 12\% C, after $20 \mathrm{~min} ; 49 \%$ A, $21 \% \mathrm{~B}$ and 30\% C, after $40 \mathrm{~min}$; and returned to $69.3 \% \mathrm{~A}, 29.7 \% \mathrm{~B}$ and $1 \% \mathrm{C}$, after $50 \mathrm{~min}$. Using this method there were separated, identified and quantified seven carotenoids from the tomato waste acetone extract: all-translutein, retention time $=3.37 \pm 0.04 \mathrm{~min}$; 9-cis-lutein, retention time $=4.94 \pm$ $0.06 \mathrm{~min}$; 13-cis-lutein, retention time $=5.91 \pm 0.09 \mathrm{~min}$; all-trans $\beta$-carotene, retention time $=7.97 \pm 0.03 \mathrm{~min}$; 9-cis$\beta$-carotene, retention time $=8.90 \pm 0.08 \mathrm{~min} ; 13$-cis- $\beta$-carotene, retention time $=15.09 \pm 0.05 \mathrm{~min}$; all-translycopene, retention time $=30.23 \pm 0.20 \mathrm{~min}[24]$.

In a recent study (2018) Pataro et al. showed that the integration of Pulsed Electric Fields (PEF) in the processing line of tomato fruits prior to steam blanching (SB), determined improved extractability of carotenoids from tomato peels. Thus, the combination of steam blanching (SB) with Pulsed Electric Fields (PEF) treatments in tomatoes processing, determined significant increase of the carotenoids content and the antioxidant power of the extracts from tomato peels, with a synergistic effect observed already at $60^{\circ} \mathrm{C}(37.9 \mathrm{mg} / 100 \mathrm{~g}$ fresh weight tomato peels). For identification of individual carotenoids, the tomato peel extracts were analyzed through high-performance liquid chromatography (HPLC-DAD). The separation was performed at $30^{\circ} \mathrm{C}$, on a Waters Spherisorb C18 reverse phase column $(5 \mu \mathrm{m}$ ODS2, $4.6 \mathrm{~mm} \times 250 \mathrm{~mm})$. The composition of mobile phase was acetonitrile:methanol $(30: 70, \mathrm{v} / \mathrm{v})$. The flow rate of the mobile phase through the column and the injection volume were $1.5 \mathrm{~mL} / \mathrm{min}$ and $100 \mathrm{~mL}$, respectively. The absorbance detection wavelength was $472 \mathrm{~nm}$. HPLC analyses showed that lycopene was the most predominant carotenoid in the tomato peel extracts, this carotenoid being mainly responsible for their antioxidant activity [25].

This paper presents the internal validation of a rapid and performant method for carotenoids determination (alltrans lutein, $\beta$-carotene and all-trans lycopene) in tomato waste powder by high-performance liquid chromatography (HPLC-DAD). Moreover, assessing the carotenoids content of tomato waste powder (obtained from conventional and organic tomatoes) was performed.

\section{Experimental part}

Materials and methods

$\underline{\text { Samples }}$

Tomato waste (a mixture of skins and seeds) obtained from tomato processing to juice within the Pilot Experiments Plant for Fruits and Vegetables Processing in IBA Bucharest. Tomato waste was subjected to dehydration process in a convection dryer at temperature $50^{\circ} \mathrm{C}$ to a moisture which allows their milling and conversion into powders and, at the same time, their stability in terms of quality $(7.15-7.50 \%$ moisture). The dried material was milled using Retsch mill. Till the carotenoids analysis, the samples of tomato waste powder were kept in glass jars wrapped with aluminum foil at $-20{ }^{\circ} \mathrm{C}$.

\section{$\underline{\text { Reagents }}$}

The analytical standards of all-trans lycopene and $\beta$-carotene type II, synthetic, butylated hydroxytoluene (BHT), HPLC grade methanol, n-hexane, acetone, methyl tert-butyl ether (MTBE) and dichloromethane were purchased from Sigma-Aldrich. Analytical standard of all-trans lutein was purchased from ChromaDex. Butylated hydroxytoluene (BHT), was used as antioxidant both in standard solutions and in the final extract of samples.

\section{$\underline{\text { Standard preparation }}$}

Individual stock standard solutions of all-trans lycopene $(0.1 \mathrm{mg} / \mathrm{mL})$ and $\beta$-carotene $(0.1 \mathrm{mg} / \mathrm{mL})$ were prepared in a mixture of $2 \%$ dichloromethane and $98 \%$ n-hexane, and stock solution of all-trans lutein $(0.1 \mathrm{mg} / \mathrm{mL})$ was prepared in n-hexane. Carotenoids stock solutions were stored in $40 \mathrm{~mL}$ amber screw vials with PTFE lined polypropylene caps, at temperature of $-23^{\circ} \mathrm{C}$. It was achieved a stability study of the individual stock standard solutions of carotenoids and on the basis of its results, these were prepared fortnightly. In order to develop the HPLC method for carotenoids determination of tomato waste powder adequate volumes of these analytical standards were evaporated at $40^{\circ} \mathrm{C} \pm 0.2^{\circ} \mathrm{C}$, to dryness under a nitrogen atmosphere, and residue was re-dissolved in methanol: methyl tert-butyl ether $=60: 40$ with $0.01 \%$ BHT. Individual working solution of each standard, of $5 \mu \mathrm{g} / \mathrm{mL}$ concentration was 
injected in the HPLC system. Identification of each carotenoid was achieved based on retention time and spectral data (table 1).

Table 1

ELEMENTS FOR IDENTIFICATION OF CAROTENOIDS (ALL-TRANS LYCOPENE,

\begin{tabular}{|c|c|c|c|}
\hline \multicolumn{4}{|c|}{$\beta$-CAROTENE, ALL-TRANS LUTEIN) } \\
\hline No. & Analytical standard & $\begin{array}{c}\text { Retention time } \\
\text { (min) }\end{array}$ & $\begin{array}{c}\text { Wavelength, } \\
\text { absorption maximum (nm) }\end{array}$ \\
\hline 1. & All-trans lutein & 8.06 & 446 \\
\hline 2. & $\beta$-carotene & 14.47 & 452 \\
\hline 3. & All-trans lycopene & 22.57 & 472 \\
\hline
\end{tabular}

In order to achieve the calibration levels was freshly prepared a mix of carotenoids analytical standards (alltrans lutein, all-trans lycopene, $\beta$-carotene), using as solvent methanol: MTBE $=60: 40$ with 0.01\% BHT. For this purpose, in a $10 \mathrm{~mL}$ volumetric flask, standard solutions of carotenoids are pipetted: $1.8 \mathrm{~mL}$ all-trans lutein $(0.1$ $\mathrm{mg} / \mathrm{mL}), 4 \mathrm{~mL}$ all-trans lycopene $(0.1 \mathrm{mg} / \mathrm{mL})$ and $2.6 \mathrm{~mL} \beta$-carotene $(0.1 \mathrm{mg} / \mathrm{mL})$. Then, the volumetric flask is brought to the mark with solvent (methanol: MTBE $=60: 40$ with $0.01 \%$ BHT). To achieve the calibration levels (N1$\mathrm{N5}$ ), in $2 \mathrm{~mL}$ volumetric flasks are pipetted different volumes of mix of carotenoids analytical standards, as follows: $0.05 \mathrm{~mL}$ (for $\mathrm{N} 1$ ), $0.25 \mathrm{~mL}$ (for $\mathrm{N} 2$ ), $0.50 \mathrm{~mL}$ (for N3), $1.00 \mathrm{~mL}$ (for N4) and $2.00 \mathrm{~mL}$ (for $\mathrm{N} 5$ ). Then, the volumetric flasks containing solutions of mix of carotenoids analytical standards, corresponding to the N1-N4 calibration levels, are brought to the mark with solvent (methanol: MTBE $=60: 40$ with $0.01 \%$ BHT). Solution of mix of carotenoids analytical standards, for each calibration level, was injected in the HPLC system.

\section{Sample preparation}

Extraction of carotenoids (all-trans lycopene, $\beta$-carotene, all-trans lutein) from tomato waste powder was performed according to the method described by Strati and Oreopoulou [26], with some modifications. Thus, extraction of carotenoids was achieved in acetone, in a water bath with ice, at maximum $4^{\circ} \mathrm{C}$, under nitrogen atmosphere and magnetic stirring, in three steps with $15 \mathrm{~mL}$ acetone, for $15 \mathrm{~min}$. Sample weight of tomato waste powder extracted was of $0.35-0.5 \mathrm{~g}$. Acetone extracts of tomato waste powder were collected in a $50 \mathrm{~mL}$ centrifuge vial, and then there are centrifuged (centrifuge Eppendorf $5408 \mathrm{R}$ ) at $9000 \mathrm{rpm}$, at $4^{\circ} \mathrm{C}$, for $20 \mathrm{~min}$. The supernatant was collected in an amber screw vial with PTFE lined polypropylene cap and was evaporated to dryness under nitrogen atmosphere, at $40^{\circ} \mathrm{C} \pm 0.2^{\circ} \mathrm{C}$, and then, the residue was re-dissolved in methanol: methyl tert-butyl ether = 60:40 with $0.01 \%$ BHT. The final solution was filtered through $0.45 \mu \mathrm{m}$ PTFE syringe filters (Teknokroma, PTFE Filter, blue, $0.45 \mu \mathrm{m}, 13 \mathrm{~mm}$ diameter) and $10 \mu \mathrm{L}$ were injected for HPLC analysis.

\section{Chromatographic conditions}

A Surveyor Plus (Thermo Finnigan) high performance liquid chromatograph (vacuum degasser, quaternary pump, autosampler with PELTIER sample temperature control, column compartment with PELTIER temperature control, Diode Array Detector, ChromQuest 4.2 software for data acquisition and data processing) was used for analysis of carotenoids. Carotenoids were separated on a reverse-phase C30, $3 \mu \mathrm{m}$ column $(250 \times 4.6 \mathrm{~mm})$ coupled to a $20 \times 4.6$ mm C30 guard column

(YMC Co., Kyoto, Japan) using mobile phases consisting of (A) methanol/ water (98:2, v/v), (B) methanol/ water (95:5, v/v) and (C) methyl tert-butyl ether, according to the method described by Gupta et al. [27]. The chromatographic separation was performed using gradient elution (table 2).

The injection volume was $10 \mu \mathrm{L}$, the flow rate of the mobile phase was $1.0 \mathrm{~mL} / \mathrm{min}$ and the column temperature was maintained at $20^{\circ} \mathrm{C}$. Auto sampler temperature was $4^{\circ} \mathrm{C}$. The eluting peaks were monitored at a range of 250 to $700 \mathrm{~nm}$ using PDA. Peak identification was based on retention time, spectral information and spiking technique. Peak quantification was based on the external standard method, using calibration curve and ChromQuest 4.2 software.

Table 2

GRADIENT ELUTION FOR THE CHROMATOGRAPHIC SEPARATION OF CAROTENOIDS FROM TOMATO WASTE POWDER

\begin{tabular}{|c|c|c|c|}
\hline \multirow{2}{*}{ Time (min.) } & \multicolumn{3}{|c|}{ Mobile phases } \\
\cline { 2 - 4 } & $\mathbf{A}$ & $\mathbf{B}$ & $\mathbf{C}$ \\
\hline 0.01 & 80 & 0 & 20 \\
\hline 2.00 & 0 & 80 & 20 \\
\hline 2.01 & 0 & 80 & 20 \\
\hline 22.00 & 0 & 0 & 100 \\
\hline 23.00 & 80 & 0 & 20 \\
\hline 30.00 & 80 & 0 & 20 \\
\hline
\end{tabular}


Validation study

In the case of method for determination of carotenoids (all-trans lutein, all-trans lycopene, $\beta$-carotene) from tomato waste powder it was achieved an "in house" validation study, being evaluated the following performance characteristics: linearity, accuracy, precision (repeatability, reproducibility), selectivity and sensitivity (limit of detection, limit of quantification).

$\underline{\text { Statistical analysis }}$

All analyses were performed in triplicate and the data are presented as mean \pm standard deviation. Regarding validation parameters, average for concentration values (expressed as $\mu \mathrm{g} / \mathrm{mL}$ and $\mathrm{mg} / 100 \mathrm{~g}$ ), standard deviation in repeatability $\mathrm{SD}(\mathrm{r})$ and reproducibility conditions $\mathrm{SD}(\mathrm{R})$, as well as relative standard deviation in repeatability $\mathrm{RSD}(\mathrm{r})$ and reproducibility conditions RSD(R) in \% were calculated using Microsoft Excel.

\section{Results and discussions \\ Performance of the method \\ Linearity}

Linearity was investigated with the aid of a regression line with 5 calibration levels by the method of least squares. There were achieved the calibration curves of the carotenoids taken into study, in the following concentration ranges: $0.25-18 \mu \mathrm{g} / \mathrm{mL}$ in case of all-trans lutein; $0.65-26 \mu \mathrm{g} / \mathrm{mL}$ in case of $\beta$-carotene; $1.00-40 \mu \mathrm{g} / \mathrm{mL}$ in case of all-trans lycopene. Calibration curves of the studied carotenoids are presented in figures 1-3. Table 3 shows the calibration levels (N1-N5, carried out according to the procedure described in Section "Standard preparation"), expressed in $\mu \mathrm{g} / \mathrm{mL}$, corresponding to each carotenoid, linear regression equation for each calibration curve and the regression coefficient $\left(\mathrm{R}^{2}\right)$, respectively. The linearity was checked by the correlation coefficient (acceptance criteria: $>0.990$ ), the relative standard deviation (RSD, \%) of peak areas (acceptance criteria: $<1.5 \%$ ) at all the concentration levels, the RSD, \% of retention times (acceptance criteria: $<0.5 \%$ ). Good response linearity was obtained for the carotenoids taken into study $\left(\mathrm{R}^{2}>0.998\right)$ in the ranges of standard concentrations analyzed. The relative standard deviation (RSD, $\%$ ) of peak areas was $0.64-0.88 \%$ for all-trans lutein, $0.76-0.81 \%$ for $\beta$-carotene and $0.60-0.65 \%$ for all-trans lycopene. Also, the relative standard deviation (RSD, \%) of retention times was $0.07-0.11 \%$ for all-trans lutein, 0.06 $-0.09 \%$ for $\beta$-carotene and $0.07-0.08 \%$ for all-trans lycopene. The obtained results show a good linearity of the method, being in accordance with those obtained by Strati et al. [24] and Gupta et al. [27].
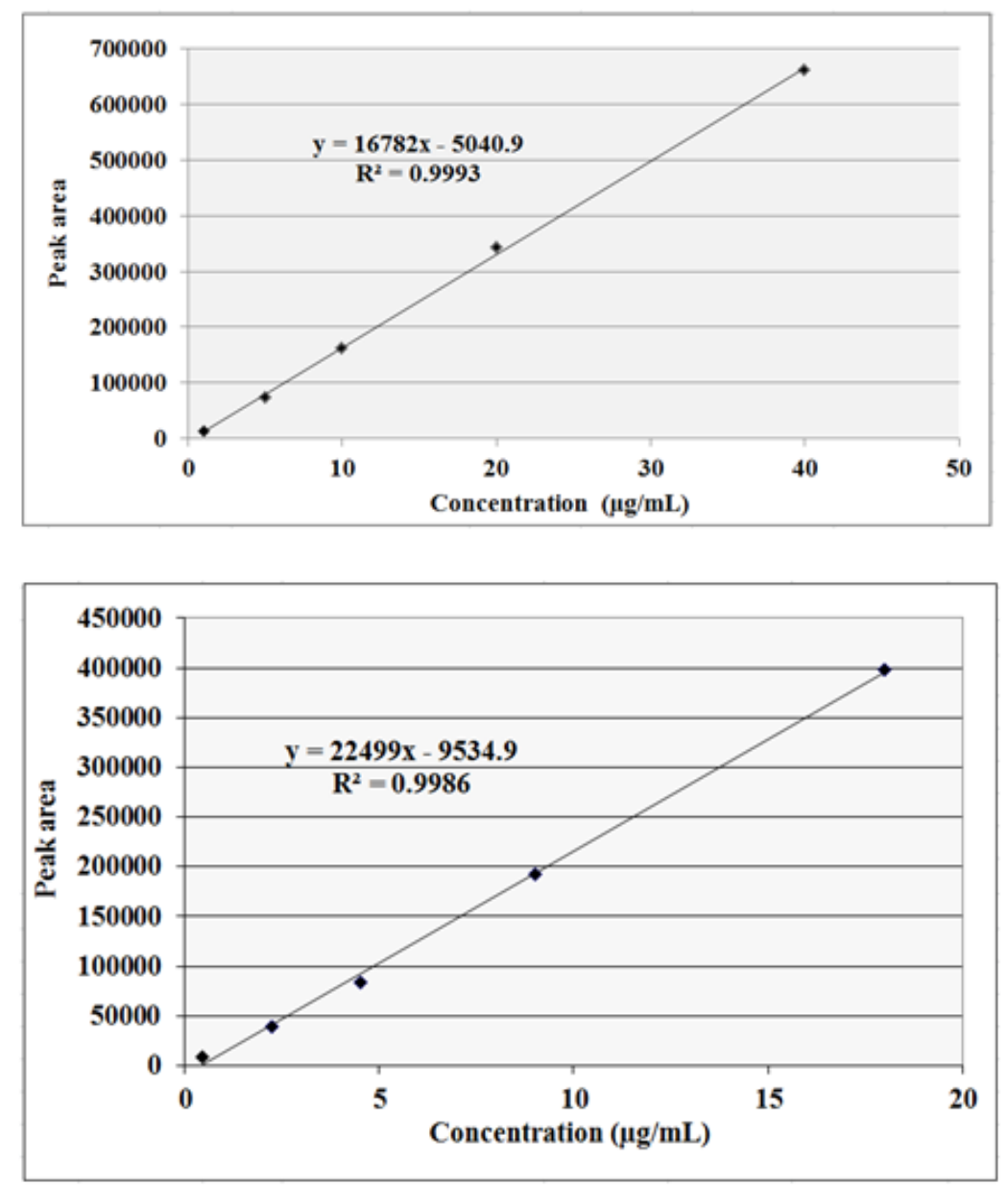

Fig. 1. Calibration curve of all-trans lycopene

Fig. 2. Calibration curve of all-trans lutein 


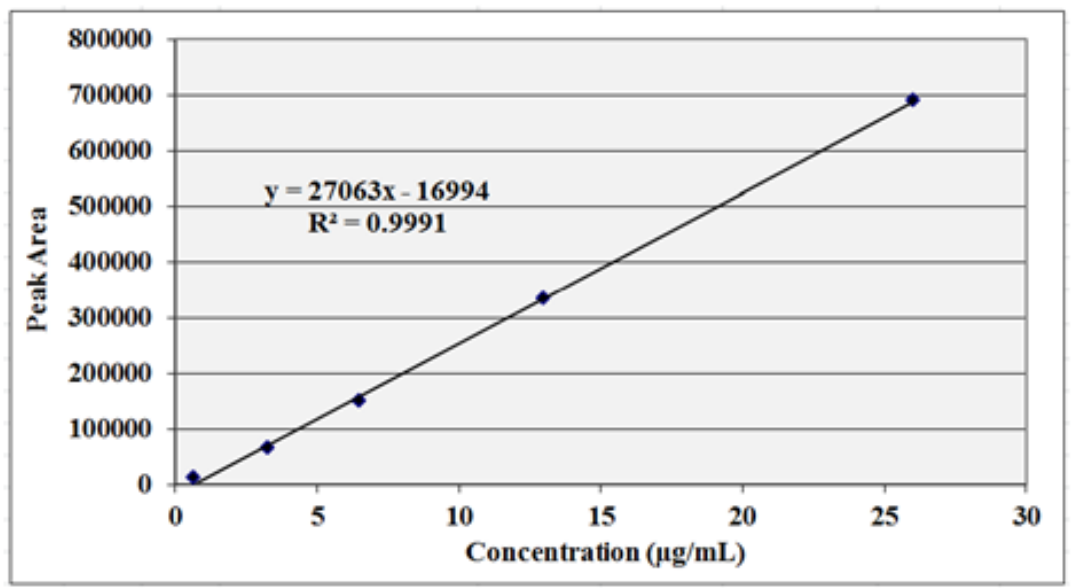

Fig. 3. Calibration curve of $\beta$-carotene

Table 3

PARAMETERS OF CALIBRATION CURVES

\begin{tabular}{|c|c|c|c|c|c|c|c|}
\hline \multirow{2}{*}{ Carotenoid } & \multicolumn{5}{|c|}{ Calibration levels $(\boldsymbol{\mu g} / \mathbf{m L})$} & Linear regression equation & $\begin{array}{c}\text { Regression } \\
\text { coefficient }\left(\mathbf{R}^{\mathbf{2}}\right)\end{array}$ \\
\cline { 2 - 6 } & $\mathbf{N 1}$ & $\mathbf{N 2}$ & $\mathbf{N 3}$ & $\mathbf{N 4}$ & $\mathbf{N 5}$ & & 0.9986 \\
\hline All-trans lutein & 0.45 & 2.25 & 4.50 & 9.00 & 18.00 & $\mathrm{y}=22499 \mathrm{x}-9534,9$ & 0.9991 \\
\hline$\beta$-carotene & 0.65 & 3.25 & 6.50 & 13.00 & 26.00 & $\mathrm{y}=27063 \mathrm{x}-16994$ & 0.9993 \\
\hline All-trans lycopene & 1.00 & 5.00 & 10.00 & 20.00 & 40.00 & $\mathrm{y}=16782 \mathrm{x}-5040,9$ & \\
\hline
\end{tabular}

\section{Accuracy}

In the absence of certified reference materials for carotenoids taken into study, accuracy was investigated by recovery [28]. Samples of tomato waste powder with determined concentration of carotenoids were spiked with two known concentrations of analytes, as following: $2.25 \mathrm{mg} / 100 \mathrm{~g}$ and $4.5 \mathrm{mg} / 100 \mathrm{~g}$ in case of all-trans lutein, $3 \mathrm{mg} / 100 \mathrm{~g}$ and $9 \mathrm{mg} / 100 \mathrm{~g}$ in case of $\beta$-carotene and $4.5 \mathrm{mg} / 100 \mathrm{~g}$ and $18 \mathrm{mg} / 100 \mathrm{~g}$ in case of all-trans lycopene. These samples were analyzed by HPLC method and it was determined the concentration of all-trans lutein, $\beta$-carotene and all-trans lycopene (there were analyzed 7 parallel samples for each addition level, and each sample was analysed in triplicate). After performing HPLC analysis, the recovery of each carotenoid was calculated by $\mathrm{R}(\%)=[(\mathrm{Cs}-\mathrm{Cp}) / \mathrm{Ca}] \times 100$, where $\mathrm{R}(\%)$ is percent recovery, $\mathrm{Cs}$ is total carotenoid content in the spiked sample, $\mathrm{Cp}$ is endogenous carotenoid content in the sample, and $\mathrm{Ca}$ is the amount of carotenoid standard added to the sample.

The average recovery for the three analytes taken into study registered the following values: $99.84 \%$ for all-trans lutein, $99.92 \%$ for $\beta$-carotene and $100.21 \%$ for all-trans lycopene. The obtained results for recovery are in accordance with the provisions of the Commission Decision 2002/657/EC [29] (Recovery $=80-120 \%$ ) and are lower in comparison to those reported by Rubashvili et al. [22]: 106.8\% for $\beta$-carotene and $101.4 \%$ for all-trans lycopene.

\section{Precision}

Precision was determined by repeatability (injection standards of carotenoids and analysis repeatability), intralaboratory reproducibility and intermediate precision. Injection repeatability was achieved by carrying out 7 consecutive injections in a short period of time (the same day). Analysis repeatability (intra-day) was determined by 7 repeated analyses of the same sample, in the same day by the same analyst and under the same experimental conditions. Intermediate precision (inter-day) was carried out by repeated analyses of the same sample in 3 different days by the same analyst and under the same experimental conditions. For evaluating the intra-laboratory reproducibility, 6 samples have been analyzed by two analysts (analyst A-3 samples, analyst B-3 samples) of tomato waste powder, performed in the same laboratory and using the same instrument (table 4). Repeatability and intermediate precision were expressed as relative standard deviation in repeatability conditions RSD (r). Intralaboratory reproducibility was expressed as relative standard deviation in reproducibility conditions $\mathrm{RSD}(\mathrm{R})$. Performance parameters of the method are presented in table 4. Acceptance criteria for precision of the method for determination of carotenoids in tomato waste powder are the following: relative standard deviation in repeatability RSD (r) $<2.00 \%$, relative standard deviation in repeatability analysis (intra-day) RSD (r) $<3.00 \%$, relative standard deviation in intermediate precision (inter-day) RSD $(\mathrm{R})<3.50 \%$ and relative standard deviation in intra-laboratory reproducibility RSD $(\mathrm{R})<5.50 \%$. Acceptance imposed criteria for precision of the method are in accordance with the provisions of Commission Decision 2002/657/EC [29]. The obtained results for precision of the method are in accordance with acceptance criteria and are comparable with those obtained by Rubashvili et al. [22] for concentration of $\beta$-carotene from tomato waste powder. The values obtained for injection and analysis repeatability, intermediate precision and intra-laboratory reproducibility showed a good precision (RSD $<5.5 \%$ ) of the method for determination of carotenoids (all-trans lutein, $\beta$-carotene and all-trans lycopene) in tomato waste powder by high-performance liquid chromatography (HPLC-DAD). 
Table 4

PERFORMANCE PARAMETERS OF THE METHOD

\begin{tabular}{|c|c|c|c|c|}
\hline \multicolumn{2}{|c|}{ Performance parameter } & \multicolumn{3}{c|}{ Analyte } \\
\cline { 3 - 5 } & All-trans lutein & $\beta$-carotene & All-trans lycopene \\
\hline \multirow{2}{|c|}{$\begin{array}{c}\text { Injection repeatability } \\
\text { (mix of carotenoids analytical } \\
\text { standards) }\end{array}$} & $\mathrm{C}(\mu \mathrm{g} / \mathrm{mL})$ & $4.49 \pm 0.04$ & $6.47 \pm 0.05$ & $10.18 \pm 0.07$ \\
\cline { 2 - 5 } & $\mathrm{RDS}(\mathrm{r})(\%)$ & 0.89 & 0.83 & 0.67 \\
\hline $\begin{array}{c}\text { Injection repeatability } \\
\text { (tomato waste powder) }\end{array}$ & $\mathrm{C}(\mathrm{mg} / 100 \mathrm{~g})$ & $2.10 \pm 0.02$ & $10.45 \pm 0.11$ & $60.73 \pm 0.50$ \\
\cline { 2 - 5 } $\begin{array}{c}\text { Analysis repeatability } \\
\text { (intra-day) }\end{array}$ & $\mathrm{RDS}(\mathrm{r})(\%)$ & 1.15 & 1.09 & 0.82 \\
\cline { 2 - 5 } & $\mathrm{C}(\mathrm{mg} / 100 \mathrm{~g})$ & $2.03 \pm 0.04$ & $11.02 \pm 0.21$ & $64.01 \pm 0.65$ \\
\hline $\begin{array}{c}\text { Intermediate precision } \\
\text { (inter-day) }\end{array}$ & $\mathrm{CDS}(\mathrm{r})(\%)$ & 2.14 & 1.90 & $64.72 \pm 0.79$ \\
\cline { 2 - 5 } & $\mathrm{RDS} / \mathrm{R})(\%)$ & $2.05 \pm 0.05$ & $11.15 \pm 0.25$ & 1.23 \\
\hline Intra-laboratory reproducibility & $\mathrm{C}(\mathrm{mg} / 100 \mathrm{~g})$ & $2.12 \pm 0.07$ & $10.79 \pm 0.29$ & $64.29 \pm 1.01$ \\
\cline { 2 - 5 } & $\mathrm{RDS}(\mathrm{R})(\%)$ & 3.07 & 2.68 & 1.57 \\
\hline
\end{tabular}

Selectivity

Selectivity was demonstrated by chromatographic separation of carotenoids (all-trans lutein, $\beta$-carotene and alltrans lycopene) in the presence of other components from the tomato waste powder (fig. 4).

Sensitivity

Sensitivity was characterized by limit of detection (LOD) and limit of quantification (LOQ). Limit of detection (LOD) represents concentration at which signal/noise ratio is higher than 3 ( $\mathrm{S} / \mathrm{N}>3)$. Limit of quantification (LOQ) is defined as being the lowest concentration of analyte which can be determined with an acceptable precision, in the conditions of a method of analysis, at a signal/noise ratio higher than $10(\mathrm{~S} / \mathrm{N}>10)$. The $\mathrm{S} / \mathrm{N}$ ratio was calculated by the Chrom Quest 4.2 software. Limit of detection and limit of quantification for those three carotenoids (all-trans lutein, $\beta$-carotene and all-trans lycopene) from tomato waste powder are presented in table 5.

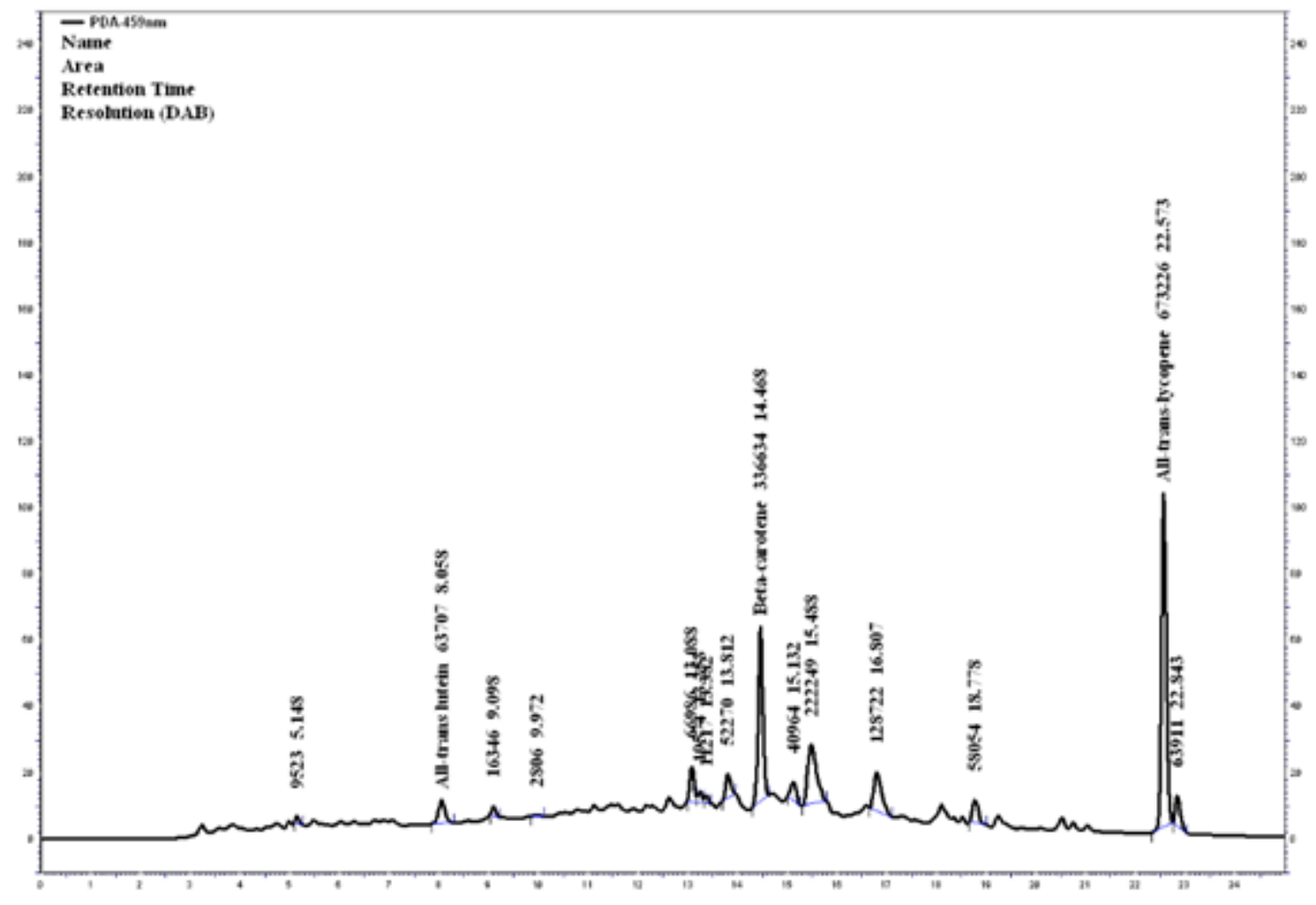

Fig. 4. Chromatogram of tomato waste powder extract (all-trans lutein: retention time $=8.058 \mathrm{~min}$; $\beta$-carotene: retention time $=14.468 \mathrm{~min}$; all-trans lycopene: retention time $=22.573 \mathrm{~min}$ )

Table 5

SENSITIVITY OF THE METHOD

\begin{tabular}{|c|c|c|c|c|c|}
\hline No. & Analyte & $\begin{array}{c}\text { LOD } \\
(\boldsymbol{\mu g} / \mathbf{m L})\end{array}$ & $\begin{array}{c}\text { LOD } \\
(\mathbf{m g} / \mathbf{1 0 0 g})\end{array}$ & $\begin{array}{c}\mathbf{L O Q} \\
(\boldsymbol{\mu g} / \mathbf{m L})\end{array}$ & $\begin{array}{c}\text { LOQ } \\
(\mathbf{m g} / \mathbf{1 0 0 g})\end{array}$ \\
\hline 1. & All-trans lutein & 0.161 & 0.483 & 0.484 & 1.452 \\
\hline 2. & $\beta$-carotene & 0.216 & 0.648 & 0.650 & 1.950 \\
\hline 3. & All-trans lycopene & 0.333 & 0.999 & 1.000 & 3.000 \\
\hline
\end{tabular}


Limit of detection and limit of quantification obtained for $\beta$-carotene and all-trans lycopene were higher than those reported by Rubashvili et al. [22] ( $\beta$-carotene: $\mathrm{LOD}=0.00405 \mu \mathrm{g} / \mathrm{mL}$ and $\mathrm{LOQ}=0.0081 \mu \mathrm{g} / \mathrm{mL}$; all-trans lycopene: $\mathrm{LOD}=0.0085 \mu \mathrm{g} / \mathrm{mL}$ and $\mathrm{LOQ}=0.034 \mu \mathrm{g} / \mathrm{mL})$.

\section{Method application}

Method developed and validated was applied for determination of carotenoids content of tomato waste powder, obtained through tomatoes processing as juice, according to the procedure described in Section "Samples". For this aim were used conventional and organic tomatoes. Table 6 shows the carotenoids content of tomato waste powders (Samples 1...5), achieved from the processing of five conventional tomato samples, as juice and, respectively, of the other three samples of tomato waste powders (Samples 1...3), achieved from the processing of organic tomatoes. Carotenoids content (all-trans lutein, $\beta$-carotene and all-trans lycopene) of tomato waste powder obtained from organic tomatoes was higher than carotenoids content of that obtained from conventional ones (table 6). Also, $\beta$ carotene and all-trans lycopene content of tomato waste powders, within this study was higher than carotenoids content reported by Nour et al. [23] (9.56 mg/100g $\beta$-carotene and $51.06 \mathrm{mg} / 100 \mathrm{~g}$ lycopene).

Table 6

CAROTENOIDS CONTENT OF TOMATO WASTE POWDER

\begin{tabular}{|c|c|c|c|}
\hline \multirow{2}{*}{$\begin{array}{l}\text { Sample of tomato } \\
\text { waste powder }\end{array}$} & \multicolumn{3}{|c|}{ Analyte } \\
\hline & $\begin{array}{l}\text { All-trans lutein } \\
(\mathbf{m g} / \mathbf{1 0 0 g})\end{array}$ & $\begin{array}{c}\beta \text {-carotene } \\
(\mathrm{mg} / \mathbf{1 0 0 g})\end{array}$ & $\begin{array}{l}\text { All-trans lycopene } \\
(\mathrm{mg} / 100 \mathrm{~g})\end{array}$ \\
\hline \multicolumn{4}{|c|}{ Conventional tomatoes } \\
\hline Sample 1 & $1.715 \pm 0.019$ & $9.952 \pm 0.108$ & $60.150 \pm 0.493$ \\
\hline Sample 2 & $1.474 \pm 0.017$ & $9.645 \pm 0.105$ & $61.126 \pm 0.501$ \\
\hline Sample 3 & $1.631 \pm 0.018$ & $9.853 \pm 0.107$ & $61.845 \pm 0.507$ \\
\hline Sample 4 & $1.508 \pm 0.017$ & $9.727 \pm 0.106$ & $61.353 \pm 0.503$ \\
\hline Sample 5 & $1.800 \pm 0.021$ & $10.026 \pm 0.109$ & $61.725 \pm 0.506$ \\
\hline \multicolumn{4}{|c|}{ Organic tomatoes } \\
\hline Sample 1 & $2.120 \pm 0.024$ & $11.108 \pm 0.121$ & $63.817 \pm 0.523$ \\
\hline Sample 2 & $2.452 \pm 0.028$ & $11.587 \pm 0.126$ & $64.258 \pm 0.527$ \\
\hline Sample 3 & $1.964 \pm 0.022$ & $11.255 \pm 0.123$ & $64.855 \pm 0.532$ \\
\hline
\end{tabular}

\section{Conclusions}

An analytical method was developed and validated for separation, detection and quantification of

carotenoids (all-trans lutein, $\beta$-carotene and all-trans lycopene) in tomato waste powder by high-performance liquid chromatography (HPLC-DAD). The proposed method has a good sensitivity (LOD $=0.161-0.333 \mu \mathrm{g} / \mathrm{mL}$ and LOQ $=0.484-1.000 \mu \mathrm{g} / \mathrm{mL}$ ) and allows determination with a good precision of carotenoids in tomato waste powders, obtained through conventional and organic tomatoes processing as juice.

Carotenoids content of tomato waste powders obtained from conventional tomatoes varied in the following ranges: $1.474-1800 \mathrm{mg} / 100 \mathrm{~g}$ for all-trans lutein; $9.645-10.026 \mathrm{mg} / 100 \mathrm{~g}$ for $\beta$-carotene; $60.150-61.845 \mathrm{mg} / 100 \mathrm{~g}$ for alltrans lycopene. The tomato waste powders obtained from organic tomatoes had the carotenoids content higher in comparison to those obtained through organic tomatoes processing, as following: $1.964-2.452 \mathrm{mg} / 100 \mathrm{~g}$ for all-trans lutein; 11.108 - $11.587 \mathrm{mg} / 100 \mathrm{~g}$ for $\beta$-carotene; 63.817 - 64.855 for all-trans lycopene.

Acknowledgements: This study was achieved through Core Program, with the support of the Ministry of Research and Innovation (MCI), contract 29N/2016, project PN 16460201.

\section{References}

1. FAOSTAT. (2014). Food and Agriculture Organisation Statistics Database. Retrieved from http://www.fao.org/faostat/en/\#data.

2. BORGUINI, R.G., DA SILVA TORRES, E.A.F., Food Rev Int, 25, 2009, p. 313.

3. RAY, R.C., EL SHEIKHA, A.F., PANDA, S.H., MONTET, D., Int J Food Ferment Technol, 1, 2011 , p. 139.

4. MARTÍNEZ-VALVERDE, I., PERIAGO, M.J., PROVAN, G., CHESSON, A., J Sci Food Agric, 82, 2002 , p. 323.

5. PALOMO, I., GUTIERREZ, M., ASTUDILlO, L., RIVERA, C., Revista Chilena De Nutricion, 36, 2009 , p. 152.

6. FUENTES, E., ASTUDILLO, L., GUTIÉRREZ, M., CONTRERAS, S., Blood Coagulation and Fibrinolysis, 23,2012 , p. 109.

7. HSU, Y.M., LAI, C.H., CHANG, C.Y., FAN, C.T., CHEN, C.T., WU, C.H., Bioscience, Biotechnology and Biochemistry, 72, nr. 3, 2008, p. 677.

8. BURTON-FREEMAN, B., TALBOT, J., PARK, E., KRISHNANKUTTY, S., EDIRISINGHE, I., Molecular Nutrition and Food Research, 56, 2012, p. 622.

9. RICCIONI, G., SCOTTI, L., DI ILIO, E., BUCCIARELLI, V., Journal of Biological Regulators \& Homeostatic Agents, 25,2011 , p. 435.

10. CAPANOGLU, E., BEEKWILDER, J., BOYACIOGLU, D., DE VOS, R.C.H., HALL, R.D., Crit Rev Food Sci, 50, 2010 , p. 919.

11. SHIXIAN, Q., DAI, Y., KAKUDA, Y., SHI, J., MITTAL, G., YEUNG, D., JIANG, Y., Food Rev Int, 21, 2005 , p. 295.

12. PAPAIOANNOU, E.H., KARABELAS, A.J., Acta Biochim Pol, 59, 2012, p. 71.

13. WPTC (The World Processing Tomato Council). (2015). World production estimate as of 15 October 2015. www.wptc.to/

14. SAVATOVIĆ, S.M., GORDANA, S., ĆETKOVIĆ, G.S., ČANADANOVIĆ-BRUNET, J.M., DJILAS, S.M., Acta Period Technol, 41, 2010, p. 187.

15. GEORGE, B., KAUR, C., KHURDIYA, D.S., KAPOOR, H.C., Food Chem, 84, 2004, p. 45.

16. TOOR, R.K., SAVAGE, G.P., Food Res Int, 38, 2005, p. 487.

17. DEMIRBAS, A., Food Chem, 118, 2010, p. 504.

REV.CHIM.(Bucharest) $71 \bullet$ no. $1 \bullet 2020$ 
18. ELLER, F.J., MOSER, J.K., KENAR, J.A., TAYLOR, S.L., J Am OilChem Soc, 87, 2010, p. 755.

19. LIADAKIS, G.N., TZIA, C., OREOPOULOU, V., THOMOPOULOS, C.D., J Food Sci, 60, 1995, p. 477.

20. PERSIA, M.E., PARSONS, C.M., SCHANG, M., AZCONA, J., PoultSci, 82, 2003, p. 141.

21. ZUORRO, A., LAVECCHIA, R., MEDICI, F., PIGA, L., Food Bioprocess Technol, 6, nr. 12, 2013, p. 3499.

22. RUBASHVILI, I., TSITSAGI, M., EBRALIDZE, K., TSITSISHVILI, V., EPRIKASHVILI, L., CHKHAIDZE, M., ZAUTASHVILI, M., Eurasian J Anal Chem, 13, nr. 2, 2018, p. 1.

23. NOUR, V., PANAITE, T.D., ROPOTA, M., TURCU, R., TRANDAFIR, I., CORBU, A.R., CYTA - JOURNAL OF FOOD, 16, nr. 1, 2018, p. 222.

24. STRATI, I.F., SINANOGLOU, V.J., KORA, L., MINIADIS-MEIMAROGLOU, S., OREOPOULOU, V., Foods, 1, 2012 , p. 52.

25. PATARO, G., CARULLO, D., BAKAR SIDDIQUE, Md.A., FALCONE, M., DONSİ, F.,FERRARI, G., Journal of Food Engineering, 233 , 2018 , p. 65.

26. STRATI, I.F., OREOPOULOU, V., Food Chem., 129, 2011, p. 747.

27. GUPTA, P., SREELAKSHMI, Y., SHARMA, R., Plant Methods, 11, 2015, p. 5.

28. THOMSON, M., ELLISON, S.R.L., WOOD, R., Pure and Applied Chemistry, 74, 2002, p. 835.

29. European Commission; Commission Decision of 12 August 2002 Implementing Council Directive 96/23/EC Concerning the Performance of Analytical Methods and the Interpretation of Results, (2002/657/EC), L 221/8-36.

Manuscript received: 09.01.2019 